\title{
Gaps Between Theory and Practice: Novice Teachers' Perspectives
}

\author{
Syeda Tehzeeb Alvi \\ Lahore College Women University, Lahore \\ E-mail: tehzeebarshad@yahoo.com \\ Muhammad Shahid Zulfiqar Ali \\ University of Education, Lahore \\ E-mail: shahidzac@yahoo.com \\ Fahan Ahmad \\ International Islamic University, Islamabad \\ E-mail: farhanahmadadq@hotmail.com
}

\begin{abstract}
This study aimed to explore the novice teachers' perception of gaps between theory and practice. Novice teachers' perceptions were further explored based on teachers' gender. The survey method was used to collect the data. A questionnaire was developed by the researcher consisted of 39 items with 5 points Likert rating scale to collect data from randomly selected 600 teachers including male and female. The data were analyzed by using the mean, standard deviation, and percentage of each five points of the Likert rating scale. The results revealed that most novice teachers were applying their learned theory in their practice regarding lesson planning \& delivery, classroom management, and students' active involvement. They were not only willing to but also were applying learned theories in their practice. It also came into the knowledge that there were fewer gaps between novice teachers' theory and practice. It is recommended by the researchers suggested that these pre-service training centers should develop a strong and viable link to make the theory more practical, operational and upto-date.
\end{abstract}

Key words: Theory, practice, novice teachers, perspective, differences, effectiveness, performance

\section{Introduction}

The gaps between theory and practice, which the renowned critical educator Paulo Freire called "praxis", may keep the classroom at the highest level or may completely overwhelm the classroom. A teacher has to strike a balance between teaching ideas and actual classroom constraints. Sometimes, the practice goals of a teacher can confuse with the theoretical goals of the same teacher. Likewise, the same teacher may feel compelled to teach a certain method because of his ideas, and at the same time feel compelled to teach a certain method because of practical problems. Persky \& McLaughlin, 2017 supported the concept of a flipped classroom to bridge the gap between theory and practice in professional education. The gap between theory and practice be regulated through professional learning in the field of education by participating and practicing in the learning design of consuming, creating, connecting, and contributing (Manganello \& Passarelli, 2020).

In most cases, schools are operated to educate students and prepare them for the bright future. However, the practical goal may become confusing due to school pressure. Ira Shor (2015) pointed out 
that district-level authorizations for practices such as standardized testing or pre-packaged courses mostly confronting with the classroom practices of individual teachers. To comprehend best, understand the countless practical goals of any educational institute, Shor suggests that teachers carefully judge the institutional signs of the goals, like the statement of mission, school aims and objectives, and national standard and goals of school education.

However, some key teaching theories recommend that the students should learn to raise the question to various authorities and leaders in the Democratic Republic, which runs to meet the standard goals of education. In the book "Democracy and Education", John Dewey advises scholars to pay attention to how to combine their personal theoretical goals with the goals of employment-providing institutions, to achieve a positive effect between the two (Giroux, 2010).

Sometimes an unseen problem casts an effect on teachers and forces them to deviate from their best practice approach. Usually, such problems can be due to the limited funds of teachers. Freire suggested in the "Pedagogy of the laden," that the teachers should go to their smart goals by putting more energy on the highest goals, the key is to achieve these goals wisely. He believes that paying too much attention to the lack of cash will prevent them from seeing the various teaching methods to achieve their highest teaching goals (Freire, 2008).

The ways adopted to observe the connection between theory and practice, starting from the purpose of examining the problem and the purpose of research. Each of these completely different hybrids which gives a different way to analyze this relationship. For example, educationists have sorted out the connection between the researcher's knowledge and beliefs and the methods used to research (Burton 1994); some have discovered and analyzed the gap between theory and practice of the teacher (Jaworski 1994, 1998); Mason, 1998).

Wittmann (2001) also quoted researchers who advocated repositioning evaluation as practice. Moreover, different students emphasized that scholars should exaggerate the exchange and dissemination of analysis results (Lester 2000; Wiliam, 2002; Lester \& Bishop 1998). The research under the contextual constraints reflects the many variables related to and a part of the learning experiences of the students, which also means that the teaching process is also a very difficult action. There are multiple ways to view this problematic situation, contingent on the theoretical perspective of the teacher and his behavior. To assert the reality, it is evident that the teacher frequently counters the circumstances that force them to take decisions (Cobb, 1988; Shulman, 1987; Cooney, 1988; Carpenter, 1988; Simon, 1995; Adler, 1996 \& Crawford; Brown \& Coles, 2000; Meltzer, 2018). Such decisions involve not only in the interpretation of the classroom issues, aa well as in the awareness of these issues (Krainer \& Cooney 1996; Thompson 1992; Schoenfeld, 1999; Jaworski 1998; Meltzer, 2018).

Some analysis results confirm, the expertise, qualification, knowledge, believes, consciousness, and feelings have a real solid influence on observations. These factors should be analyzed separately, but this distinction is only theoretical and artificial because in practice they will constantly move and closely merge. Ferraz, Vidoni \& Boas, 2020 have concluded that the interaction between the different levels of school and its stakeholders may be helpful to bridge the gap between theory and practice. 


\section{Significance of the Study}

In contrast, many studies have been conducted to measure employee job satisfaction. In this study, more energy has been focused on identifying factors and key elements that need to be included to bridge the gap between theory and practice. The basic principle of this research is to show comparatively little explored theoretical fields and their implications in the actual environment.

\section{Research Objectives}

The study was guided by the following objectives:

- To determine the gap between theory and practice among novice recruited teachers 'perspectives.

- To identify the importance of theory among newly recruited perspectives in practice.

- To measure the gap between theory and practice among novice recruited teachers 'perspectives

\section{Methodology}

A quantitative method of research was applied to the collection of data. The survey method by using a questionnaire as a research instrument was applied for data collection to identify the gaps from novice recruited teachers for this study. A sample of 500 participants (250 male and 350 female was taken through a simple random sampling technique from the target population of the study consisted of 3564 male and 5486 female newly recruited teachers of 156 boys and 176 girls government high schools present in the district of Lahore.

\section{Validity and Reliability of the Questionnaire and pilot testing}

For achieving face validity, the questionnaire was validated by the opinions of the experts. The items were tested during the pilot study. One hundred questionnaires were distributed for pilot testing. one day. The SPSS was utilized for data coding and analysis. To ensure the reliability of the instrument was tested by applying the Cronbach-alpha coefficient.

Section II the researchers of the study have designed 39 statements for novice teachers with 5 points Likert Rating scale.

\section{Collection of Data}

For data collection, the designed 800 questionnaires were distributed by the researchers on their visit to different public high schools situated in the district of Lahore. After 15 days 500 questionnaires were collected back from the relevant teachers, with a return rate of $62.5 \%$ of the questionnaires.

\section{Data Analysis}

Descriptive and inferential statistics were used for data analysis.

\section{Section I (Demographic information of the participants of the Study}

Section-I consisted of the information about the participants of the study i.e., male, female, age group, educational and professional qualifications of the novice recruited teachers. 
Table1: Demographic survey (Frequency and percentage)

\begin{tabular}{lccc}
\hline Options & Frequency & Percent & Valid Percent \\
\hline Male participants & 250 & 41.67 & 41.67 \\
\hline Female participants & 350 & 58.33 & 58.33 \\
\hline Age group from 21 to 25years & 172 & 28.7 & 28.7 \\
\hline Age group from 26 to 30 years & 245 & 41.8 & 41.8 \\
\hline Age group from 31 to 35 years) & 143 & 23.8 & 23.8 \\
\hline Age group from 36 to 40 years & 40 & 6.7 & 6.7 \\
\hline Graduates (Qualification) & 387 & 65 & 65 \\
\hline Post- Graduates including M.Phil & 213 & 35 & 35 \\
\hline B.Ed, M.Ed & 428 & 71 & 71 \\
\hline BS/MS (Edu) & 172 & 29 & 29
\end{tabular}

Male participants of the study have $41.67 \%$ while female participants were $58.33 \%$, so the majority are female and $28.7 \%$ were in the age group from 21 to $25 y$ ears, $41.8 \%$ in the age group from 26 to 30 years, $23.8 \%$ in the age group from 31 to 35 years while $6.7 \%$ belong to the age group of 36 to 40 years that shows majority were young participants as they were newly recruited teachers. And $65 \%$ were the graduates and $35 \%$ were post-graduate degree holders, all the participants of the study were professionally qualified.

Section II the researchers of the study have designed 39 statements for novice teachers with 5 points Likert Rating scale.

Table 2: Percentage Standard Deviation and Mean Score of the statement

\begin{tabular}{|l|c|c|c|c|c|c|c|}
\hline \multicolumn{1}{|c|}{ Statements } & $\begin{array}{c}\text { Percent } \\
\text { age of } \\
\text { strongly } \\
\text { disagree } \\
\text { d }\end{array}$ & $\begin{array}{c}\text { Percent } \\
\text { age of } \\
\text { disagree } \\
\text { d }\end{array}$ & $\begin{array}{c}\text { Percent } \\
\text { age of } \\
\text { neutral }\end{array}$ & $\begin{array}{c}\text { Percent } \\
\text { age of } \\
\text { agreed }\end{array}$ & $\begin{array}{c}\text { Percent } \\
\text { age of } \\
\text { strongly } \\
\text { agreed }\end{array}$ & $\begin{array}{c}\text { Mean } \\
\text { score }\end{array}$ & $\begin{array}{c}\text { Standa } \\
\text { rd } \\
\text { Deviati } \\
\text { on }\end{array}$ \\
\hline $\begin{array}{l}\text { Find more ways to } \\
\text { comprehend my } \\
\text { students' thinking } \\
\text { in related subjects }\end{array}$ & 56.4 & 31.6 & 4.8 & 4.6 & 2.6 & 4.10 & .883 \\
\hline $\begin{array}{l}\text { Provide details to } \\
\text { stakeholders reason } \\
\text { for choosing in the } \\
\text { organization of the } \\
\text { course work }\end{array}$ & 62.6 & 29.4 & 2.8 & 3.2 & 2 & 4.15 & .773 \\
\hline $\begin{array}{l}\text {. Carefully review } \\
\text { the students' work }\end{array}$ & 63.6 & 27.8 & 2.8 & 2.6 & 1.8 & 4.11 & .789 \\
\hline
\end{tabular}


to study whether it is necessary to reteach specific concepts in related subjects

Understanding a student's difficulty in some area, always help the student to overcome it

If students encounter difficulties in adopting the first method, please modify the course "on the spot"

I understand some ideas, but I don't know how to teach

\begin{tabular}{|c|c|c|c|c|c|c|c|}
\hline $\begin{array}{l}\text { Adopt several } \\
\text { strategies to } \\
\text { encourage students } \\
\text { to show their ideas } \\
\text { in the subjects } \\
\text { taught. }\end{array}$ & 52 & 29.2 & 6 & 10 & 2.8 & 3.99 & .941 \\
\hline $\begin{array}{l}\text { Talk to colleagues } \\
\text { about students' } \\
\text { misconceptions to } \\
\text { get another } \\
\text { perspective }\end{array}$ & 52.6 & 34.6 & .5 .4 & 5.2 & 2.2 & 4.12 & .894 \\
\hline $\begin{array}{l}\text { Accurately assess } \\
\text { students' ability to } \\
\text { perform procedures } \\
\text { in the subjects } \\
\text { taught. }\end{array}$ & 57.2 & 32.8 & 4.4 & 3.2 & 2.4 & 4.14 & .857 \\
\hline $\begin{array}{l}\text { Discover that there } \\
\text { is still a lot of }\end{array}$ & 46.8 & 36.4 & 8 & 6.2 & 2.6 & 4.06 & .989 \\
\hline
\end{tabular}


knowledge about how people learn.

Have sufficient
subject knowledge to teach well at the assigned grade level

Analyze the course materials and consider how to maximize the learning effect.

. Participate in professional development activities to improve my efficiency as a teacher.

Show enthusiasm for the subject in class.

Organize and manage effective cooperative learning activities.

\begin{tabular}{|c|c|c|c|c|c|c|c|}
\hline $\begin{array}{l}\text { Need to know } \\
\text { more about how } \\
\text { students actually } \\
\text { learn. }\end{array}$ & 54.4 & 33.2 & 5.6 & 4.6 & 2.2 & 4.11 & .889 \\
\hline $\begin{array}{l}\text { Organize and } \\
\text { manage effective } \\
\text { class discussions on } \\
\text { the subject. }\end{array}$ & 51 & 32.2 & 7 & 6.8 & 3 & 4.02 & .970 \\
\hline $\begin{array}{l}\text { Use teaching } \\
\text { strategies that } \\
\text { encourage students } \\
\text { to think about and } \\
\text { use their prior } \\
\text { knowledge of the } \\
\text { topics taught. }\end{array}$ & 58 & 32.2 & 3.2 & 4.8 & 1.8 & 4.16 & .798 \\
\hline In class & 56.8 & 24 & 5.6 & 12.4 & 1.2 & 3.97 & .834 \\
\hline
\end{tabular}


discussions, use one or more routines to answer incorrect answers

Use various skills to teach

Need to know more about how to teach

Spend time reflecting on subject lessons after teaching Let students see that they are still learning topics and teaching.

There are different strategies to teach different subject content.

\begin{tabular}{|c|c|c|c|c|c|c|c|}
\hline $\begin{array}{l}\text { Help students } \\
\text { develop enthusiasm } \\
\text { for the subjects } \\
\text { taught }\end{array}$ & 55.6 & 33.8 & 4.8 & 4.2 & 1.6 & 4.15 & .833 \\
\hline $\begin{array}{l}\text { Design teaching } \\
\text { tasks to effectively } \\
\text { help students learn } \\
\text { the expected topics }\end{array}$ & 47.6 & 35.2 & 2.8 & 12.8 & 1.6 & 4.12 & .850 \\
\hline $\begin{array}{l}\text { Know why students } \\
\text { encounter certain } \\
\text { difficulties in } \\
\text { teaching topics }\end{array}$ & 53.6 & 38.2 & 3.8 & 3 & 1.4 & 4.23 & .798 \\
\hline $\begin{array}{l}\text { For each class, } \\
\text { there must be clear } \\
\text { goals, which } \\
\text { should be based on } \\
\text { the standards of the } \\
\text { subjects taught. }\end{array}$ & 50 & 32.2 & 6.4 & 9.6 & 1.4 & 4.06 & .895 \\
\hline $\begin{array}{l}\text { Tend to encourage } \\
\text { students to put } \\
\text { forward their own }\end{array}$ & 51.6 & 35 & 5.8 & 5.8 & 1.8 & 4.12 & .888 \\
\hline
\end{tabular}


ideas, and then as a whole, resolve any confusion caused.

\begin{tabular}{|c|c|c|c|c|c|c|c|}
\hline $\begin{array}{l}\text { Know how to } \\
\text { improve teaching } \\
\text { and students' } \\
\text { subject } \\
\text { proficiency. }\end{array}$ & 50.6 & 37.4 & 4 & 6.2 & 1.8 & 4.18 & .853 \\
\hline $\begin{array}{l}\text { Some topics are } \\
\text { there which I } \\
\text { understand but do } \\
\text { not know how } \\
\text { students learn } \\
\text { them. }\end{array}$ & 53.8 & 35 & 3.2 & 6 & 2 & 4.17 & .832 \\
\hline $\begin{array}{l}\text { Using students' } \\
\text { ideas to help the } \\
\text { class fellows to } \\
\text { learn. }\end{array}$ & 43.2 & 40.2 & 5.8 & 8.4 & 1.8 & 4.15 & .930 \\
\hline $\begin{array}{l}\text { In the teaching } \\
\text { process, I evaluate } \\
\text { students' } \\
\text { understanding of } \\
\text { the concepts of the } \\
\text { subjects taught. }\end{array}$ & 50.4 & 33.4 & 4.6 & 8.6 & 3 & 4.07 & .933 \\
\hline $\begin{array}{l}\text { One of the more } \\
\text { ways I learn about } \\
\text { teaching is to } \\
\text { analyze what is } \\
\text { happening in the } \\
\text { classroom. }\end{array}$ & 43.6 & 35.2 & 6 & 12.6 & 2.6 & 4.03 & .976 \\
\hline $\begin{array}{l}\text { Reviewing students' } \\
\text { assignments to } \\
\text { evaluate with all } \\
\text { strengths and } \\
\text { weaknesses of the } \\
\text { students. }\end{array}$ & 58.8 & 29.2 & 4.4 & 6.2 & 1.4 & 4.10 & .805 \\
\hline $\begin{array}{l}\text { If I first } \\
\text { demonstrate how } \\
\text { to solve the } \\
\text { problem and then } \\
\text { instruct them in } \\
\text { practice, I think the }\end{array}$ & 53.6 & 29.6 & 5 & 8 & 3.8 & 4.00 & .959 \\
\hline
\end{tabular}




\begin{tabular}{|l|l|l|l|l|l|l|l|}
\hline students learn best. & & & & & & & \\
\hline $\begin{array}{l}\text { While planning, I } \\
\text { emphasized to } \\
\text { prepare for my } \\
\text { students the } \\
\text { subjects to be } \\
\text { studied next year }\end{array}$ & 47.6 & 35.8 & 6 & 8 & 2.6 & 4.08 & .953 \\
\hline $\begin{array}{l}\text { In my class, } \\
\text { students have the } \\
\text { opportunity to use } \\
\text { multiple } \\
\text { representations of } \\
\text { the courses taught. }\end{array}$ & 55.6 & 31.6 & 4.4 & 6.2 & 2 & 4.11 & .852 \\
\hline $\begin{array}{l}\text { During instruction, } \\
\text { I respond } \\
\text { effectively to my } \\
\text { students' } \\
\text { questions. }\end{array}$ & 56.8 & 29 & 7.8 & 4.8 & 1.4 & 4.04 & .882 \\
\hline
\end{tabular}

\section{Summary}

The research aims to understand "the gap between theory and practice: novice recruiting teachers "perspective". In contrast, many studies have been conducted to measure employee job satisfaction. Therefore, this research focuses more on identifying the components that needed to be included to narrow down the gaps between the learned theory and its application into practice. The basic principle of current research is to show relatively little explored theoretical fields with their practicability in the actual classroom situation. Few major types of research have been made to check teacher satisfaction to discover the gaps between theory and practice. The purpose of this research is to discover gaps between theory and practice according to the viewpoints of new teachers. The research methodology includes research population, sample, design, tool development for the research. The validity and reliability of the research instrument (questionnaire) through a pilot test,, for the collection and analysis of data descriptive and inferential statistics was applied. In the current study, quantitative methods were applied, and collected data was analyzed and interpreted. The data was gathered from newly recruited teachers of both genders with different age groups and different academic and professional qualifications from the public schoolteachers in government secondary schools in Lahore.

\section{Discussion}

The research has concluded that the majority of novice teachers and educators, after completing their pre-service training feel comfortable in applying their attained techniques in their practical work experiences, efforts are made to utilize their professional theory in their classroom environment particularly in the classroom management, student's involvement and lesson planning to make their lesson effective and efficient for their students. Analysis and evaluation of the attained data show that 
some gaps are found in theories and their practical implications in the perspective of novice recruited teachers. Teaching methodologies learned theoretically during their professional training were found very much helpful for them. Almost all of the newly recruited teachers feel themselves comfortable working independently and find themselves passionate and enthusiastic to apply their professional training. The research finds that the novice teachers

○ fully understand the importance of students' psychological needs,

○ make maximum efforts for students' participation,

○ make careful efforts for checking and reviewing students' assignments

* Facilitate and guide their students in overcoming their learning and adjustment problems.

* Use different strategies to encourage their students to express their point of view and difficulties

* Find themselves ready to handle non-routine difficulties effectively

They find some problems in time management, utilizing students' feedback, and task-based learning to make their teaching experiences more effective which has been proved through the findings of the study. The study proved that the learned theories and methodologies have a positive and fruitful impact brought by in-service and pre-service pieces of training which make them fully conscious about the requirements and essentials of the classroom environment.

\section{Recommendations}

The researchers have made the following commendations:

- It is recommended that further research be carried out as it is an informative and new topic of great importance to bring effectiveness and efficiency in the performance of the newly recruited teachers' perspective.

- Moreover, it is recommended that an in-depth quantitative and qualitative study may also be employed to explore the gaps between theory and practice and scope be increased to the other districts of Pakistan even bifurcating urban and rural areas. The scope of the research work be enhanced and more research must be carried out to see the level of application of the taught theories in the workplaces of the teachers to achieve excellence.

- To ensure the accuracy of the responses to the questionnaire it is recommended to be verified them by the headteachers to explore the gap between theory and practice.

- The researcher has also recommended that the missing but required areas must be identified so that an addition be made in the syllabus and curriculum of the training courses to make it updated and well versed according to the needy schools.

\section{References:}


1. Bishop-Clark, C., \& Lynch, J. (1998). Comparing teacher and student responses to the mixedage college classroom. Community College Review, 25(4), 21-34...

2. Brown, L., \& Coles, A. (2000). Complex decision-making in the classroom: The teacher as an intuitive practitioner. The intuitive practitioner: On the value of not always knowing what one is doing, 165-181.

3. Cooney, T. J., \& Krainer, K. (1996). Inservice mathematics teacher education: The importance of listening. In International handbook of mathematics education (pp. 1155-1185). Springer Netherlands.

4. Cooney, T. M., Schaie, K. W., \& Willis, S. L. (1988). The relationship between prior functioning on cognitive and personality dimensions and subject attrition in longitudinal research. Journal of Gerontology, 43(1), P12-P17.

5. Dewey, J. (1902). The school is a social center. The Elementary School Teacher, 3(2), 73-86.

6. Educational Studies in Mathematics, 48(1), 1-20.

7. Ferraz, O. L., Vidoni, C., \& Boas, M. V. (2020). Bridging the gap between theory and practice: the impact of school-university partnership in a PETE program. Sport, Education and Society, 112.

8. Freire, P. (2008). 2.2 Teachers as cultural workers. Handbook of research on teacher education: Enduring questions in changing contexts, 208.

9. Giroux, H. (2010). Lessons from Paulo Freire. Chronicle of Higher Education, 57(9), B15-B16.

10. Jaworski, B. (1998). Mathematics teacher research: Process, practice, and the development of teaching. Journal of Mathematics Teacher Education, 1(1), 3-31.

11. K., \& Adler, J. (1996). Teachers as researchers in mathematics education. In In3ternational handbook of mathematics education (pp. 1187-1205). Springer Netherlands.

12. Lester, B. T., Ma, L., Lee, O., \& Lambert, J. (2006). Social activism in elementary science education: A science, technology, and society approach to teaching global warming. International Journal of Science Education, 28(4), 315-339.

13. Lester, J. H. (2000). Secondary instruction: Does literacy fit in?. The High School Journal, 83(3), 10-16.

14. Manganello, D., Persico, F., \& Passarelli, M. (2020). Participatory approaches to learning design: the gap between theory and practice. Interaction Design and Architectures JournalIxD\&A, 44, 96-108.

15. Mason, J. (2002). Researching your own practice: The discipline of noticing. Routledge.

16. Meltzer, L. (Ed.). (2018). Executive function in education: From theory to practice. Guilford Publications.

17. P. (1988). The tension between theories of learning and instruction in mathematics education. Educational psychologist, 23(2), 87-103.

18. Persky, A. M., \& McLaughlin, J. E. (2017). The flipped classroom-from theory to practice in health professional education. American journal of pharmaceutical education, 81(6).

19. Schoenfeld, A. H. (1989). Explorations of students' mathematical beliefs and behavior. Journal for research in mathematics education, 338-355. 
20. Schoenfeld, A. H. (1999). Looking toward the 21st century: Challenges of educational theory and practice. Educational researcher, 28(7), 4-14.

21. Shulman, L. (1987). Knowledge and teaching: Foundations of the new reform. Harvard educational review, 57(1), 1-23.

22. Shulman, L. S. (1986). Those who understand: Knowledge growth in teaching. Educational researcher, 15(2), 4-14.

23. Simon, G. E. 1995). Collaborative management to achieve treatment guidelines: impact on depression in primary care. Jama, 273(13), 1026-1031.

24. Simon, M. A., \& Schifter, D. (1991). Towards a constructivist perspective: An intervention study of mathematics teacher development. Educational Studies in Mathematics, 22(4), 309-331.

25. Thompson, A. G. (1992). Teachers' beliefs and conceptions: A synthesis of the research.

26. Wiliam, D. (2002). On the purpose of mathematics education research: Making productive contributions to policy and practice. Handbook of international research in mathematics education, 489-506.

27. Williams, W. M. (2002). Teaching Children Real-World Knowledge and Reasoning. Developmental Review, 22(2), 151-161.

28. Wittmann, E. C. (2001). Developing mathematics education in a systemic process. 